\title{
The Aerodynamic Performance of an Over-the-Rotor Liner With Circumferential Grooves on a High Bypass Ratio Turbofan Rotor
}

Richard F. Bozak and Christopher E. Hughes

Glenn Research Center, Cleveland, Ohio

James Buckley

Vantage Partners, Brook Park, Ohio 


\section{NASA STI Program . . . in Profile}

Since its founding, NASA has been dedicated to the advancement of aeronautics and space science. The NASA Scientific and Technical Information (STI) program plays a key part in helping NASA maintain this important role.

The NASA STI Program operates under the auspices of the Agency Chief Information Officer. It collects, organizes, provides for archiving, and disseminates NASA's STI. The NASA STI program provides access to the NASA Aeronautics and Space Database and its public interface, the NASA Technical Reports Server, thus providing one of the largest collections of aeronautical and space science STI in the world. Results are published in both non-NASA channels and by NASA in the NASA STI Report Series, which includes the following report types:

- TECHNICAL PUBLICATION. Reports of completed research or a major significant phase of research that present the results of NASA programs and include extensive data or theoretical analysis. Includes compilations of significant scientific and technical data and information deemed to be of continuing reference value. NASA counterpart of peer-reviewed formal professional papers but has less stringent limitations on manuscript length and extent of graphic presentations.

- TECHNICAL MEMORANDUM. Scientific and technical findings that are preliminary or of specialized interest, e.g., quick release reports, working papers, and bibliographies that contain minimal annotation. Does not contain extensive analysis.

- CONTRACTOR REPORT. Scientific and technical findings by NASA-sponsored contractors and grantees.
- CONFERENCE PUBLICATION. Collected papers from scientific and technical conferences, symposia, seminars, or other meetings sponsored or cosponsored by NASA.

- SPECIAL PUBLICATION. Scientific, technical, or historical information from NASA programs, projects, and missions, often concerned with subjects having substantial public interest.

- TECHNICAL TRANSLATION. Englishlanguage translations of foreign scientific and technical material pertinent to NASA's mission.

Specialized services also include creating custom thesauri, building customized databases, organizing and publishing research results.

For more information about the NASA STI program, see the following:

- Access the NASA STI program home page at http://www.sti.nasa.gov

- E-mail your question to help@sti.nasa.gov

- Fax your question to the NASA STI Information Desk at 443-757-5803

- Phone the NASA STI Information Desk at 443-757-5802

- Write to: STI Information Desk NASA Center for AeroSpace Information 7115 Standard Drive Hanover, MD 21076-1320 


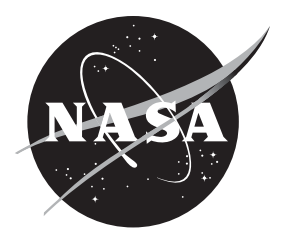

\section{The Aerodynamic Performance of an Over-the-Rotor Liner With Circumferential Grooves on a High Bypass Ratio Turbofan Rotor}

Richard F. Bozak and Christopher E. Hughes

Glenn Research Center, Cleveland, Ohio

James Buckley

Vantage Partners, Brook Park, Ohio

Prepared for the

Turbo Expo 2013

sponsored by the American Society of Mechanical Engineers (ASME)

San Antonio, Texas, June 3-7, 2013

National Aeronautics and

Space Administration

Glenn Research Center

Cleveland, Ohio 44135 


\section{Acknowledgments}

The authors would like to thank Daniel Tweedt of AP Solutions for his aerodynamic analysis and design of the over-the-rotor rub strip. Thanks also to the W-8 test cell crew: Julia Stephens, Brent Seifert, Bruce Wright, James Knight, and Jason Bryant. This work was supported by the Environmentally Responsible Aviation Project of NASA's Integrated Systems Research Program.

Trade names and trademarks are used in this report for identification only. Their usage does not constitute an official endorsement, either expressed or implied, by the National Aeronautics and Space Administration.

Level of Review: This material has been technically reviewed by technical management.

Available from

NASA Center for Aerospace Information 7115 Standard Drive

Hanover, MD 21076-1320
National Technical Information Service 5301 Shawnee Road Alexandria, VA 22312

Available electronically at http://www.sti.nasa.gov 


\title{
The Aerodynamic Performance of an Over-the-Rotor Liner With Circumferential Grooves on a High Bypass Ratio Turbofan Rotor
}

\author{
Richard F. Bozak and Christopher E. Hughes \\ National Aeronautics and Space Administration \\ Glenn Research Center \\ Cleveland, Ohio 44135 \\ James Buckley \\ Vantage Partners \\ Brook Park, Ohio 44142
}

\begin{abstract}
While liners have been utilized throughout turbofan ducts to attenuate fan noise, additional attenuation is obtainable by placing an acoustic liner over-the-rotor. Previous experiments have shown significant fan performance losses when acoustic liners are installed over-the-rotor. The fan blades induce an oscillating flow in the acoustic liners which results in a performance loss near the blade tip. An over-the-rotor liner was designed with circumferential grooves between the fan blade tips and the acoustic liner to reduce the oscillating flow in the acoustic liner. An experiment was conducted in the W-8 Single-Stage Axial Compressor Facility at NASA Glenn Research Center on a 1.5 pressure ratio fan to evaluate the impact of this over-the-rotor treatment design on fan aerodynamic performance. The addition of a circumferentially grooved over-the-rotor design between the fan blades and the acoustic liner reduced the performance loss, in terms of fan adiabatic efficiency, to less than 1 percent which is within the repeatability of this experiment.
\end{abstract}

\section{Introduction}

While the use of air transportation continues to grow, the reduction of negative environmental impacts will become increasingly challenging. The Environmentally Responsible Aviation (ERA) Project of NASA's Integrated Systems Research Program is working to develop technologies to reduce the impact of commercial aircraft on the environment. Specifically, the project is working to improve fuel efficiency, reduce emissions, and reduce noise. The noise from turbofan engines on commercial aircraft is a major contributor to airport community noise. Increasing bypass ratios have elevated the impact of fan noise relative to the other noise sources in turbofan engines. Acoustic liners have been developed and utilized to reduce both tonal and broadband noise levels within the fan duct.

While liners within fan ducts have successfully reduced engine noise, additional acoustic benefits are possible if a liner is installed over-the-rotor. A series of acoustics and fan performance tests at NASA Glenn Research Center have explored the impact of installing a foam-metal liner over-therotor. First, a foam-metal liner was developed for broadband attenuation and tested on a low-speed fan. This liner reduced fan noise by $4 \mathrm{~dB}$ in broadband sound pressure level (Ref. 1). Then in 2008, an over-the-rotor foam-metal liner was installed on an ultra-high bypass fan model in the 9x15 Low-Speed Wind Tunnel. The results from this test showed a reduction of up to $1 \mathrm{~dB}$ in overall acoustic power level (OAPWL) (Ref. 2), with a loss in fan aerodynamic efficiency between 3.75 and 8.75 percent (Ref. 3). In addition to the significant loss in efficiency, the perforated plate covering the foam-metal liner caused damage to the composite fan blade tips. Another foammetal liner over-the-rotor was evaluated on a static engine test of a Williams International FJ44-3A (Ref. 4). The foam-metal liner was installed over-the-rotor and behind holes in the valleys of the circumferential grooves. The static engine test showed an OAPWL reduction of $2.5 \mathrm{~dB}$, while reducing engine performance between 0.5 and 2 percent. The ability of this treatment design to reduce noise, while having less of an effect on fan performance, when compared to other over-therotor liners, has been attributed to the addition of circumferential grooves around the fan casing.

Circumferentially grooved casing treatments were examined in the 1970s because of their ability to increase the flow range capability of single-stage axial compressors with no significant effect on efficiency (Ref. 5). Increasing the flow range enables fan or compressor operation at higher speed conditions with sufficient stall margin, which could result in a net increase in efficiency. Hathaway (Ref. 6) summarized the important over-the-rotor circumferential groove parameters. In order for a design to improve the flow range without significantly impacting efficiency, the middle 60 percent of the rotor chord should be treated, the grooves should have 65 to 75 percent open area, and the grooves should be 3 times as deep as they are wide (Ref. 6). The ability of circumferential grooves to improve the flow range without significantly impacting efficiency has led to its use in modern turbofans.

An over-the-rotor treatment was designed for testing in the 9x15 Low-Speed Wind Tunnel. This treatment incorporates circumferential grooves over-the-rotor. The over-the-rotor grooves were designed and modeled by Daniel Tweedt of AP 
Solutions Inc. In order to reduce the risk of finding significant performance losses in an expensive wind tunnel test, the overthe-rotor treatment design was tested in the W-8 Single Stage Axial Compressor Facility. The test included pressure and temperature measurements to examine the performance losses. The results of this test are presented.

\section{Nomenclature}

SDT Source Diagnostic Test

OAPWL overall acoustic power level

$\mathrm{RPM}_{\mathrm{c}} \quad$ corrected revolutions per minute

PR total pressure ratio

FPR area averaged fan pressure ratio

TR total temperature ratio

FTR area averaged fan temperature ratio

$\gamma \quad$ ratio of specific heats

$\eta_{\text {adiabatic }}$ adiabatic efficiency

FAE area averaged fan adiabatic efficiency

\section{Test Facility}

The test was conducted in the W-8 Single-Stage Axial Compressor Facility at NASA Glenn Research Center. A schematic of the facility is shown in Figure 1. The facility is capable of delivering up to $7,000 \mathrm{hp}(5,220 \mathrm{~kW})$ at speeds up to $21,240 \mathrm{rpm}$ to a 22 in. $(0.559 \mathrm{~m})$ diameter fan or compressor. Up to $100 \mathrm{lb} / \mathrm{s}(45.4 \mathrm{~kg} / \mathrm{s})$ of air is provided from an atmospheric inlet, or a dry pressurized air source. Flow conditioning screens in the inlet plenum reduce the turbulence intensity at the fan to less than 1 percent. In order to provide a flight-like boundary layer entering the fan, up to $4.5 \mathrm{lb}_{\mathrm{m}} / \mathrm{s}$ $(2.0 \mathrm{~kg} / \mathrm{s})$ of air is pulled through a bleed slot about $10 \mathrm{in}$. $(0.25 \mathrm{~m})$ upstream of the fan. The flow through the facility is controlled by a sleeve throttle valve. The air can be exhausted through an atmospheric exhaust system or an altitude exhaust system. Facility instrumentation includes up to 400 channels of steady pressure and thermocouple measurement, tip clearance sensing, and up to 96 channels of high speed rotating fan data. The steady pressure and temperature measurements presented were acquired at $1 \mathrm{~Hz}$ and then averaged over a 10 seconds.

Since the primary objective of this test was to determine the performance loss associated with a new over-the-rotor treatment design, a subset of the facility capabilities was utilized. In order to increase the facility flow capacity, the inlet orifice plate was removed. The boundary layer bleed was used to full capacity, in order to mimic the conditions in the 9x15 Low-Speed Wind Tunnel. The corrected mass flow removed through the bleed slot was approximately $4.5 \mathrm{lb}_{\mathrm{c}} / \mathrm{s}$ $\left(2.0 \mathrm{~kg}_{\mathrm{c}} / \mathrm{s}\right)$ for all conditions presented. Only the atmospheric inlet and atmospheric exhaust were used for this test.

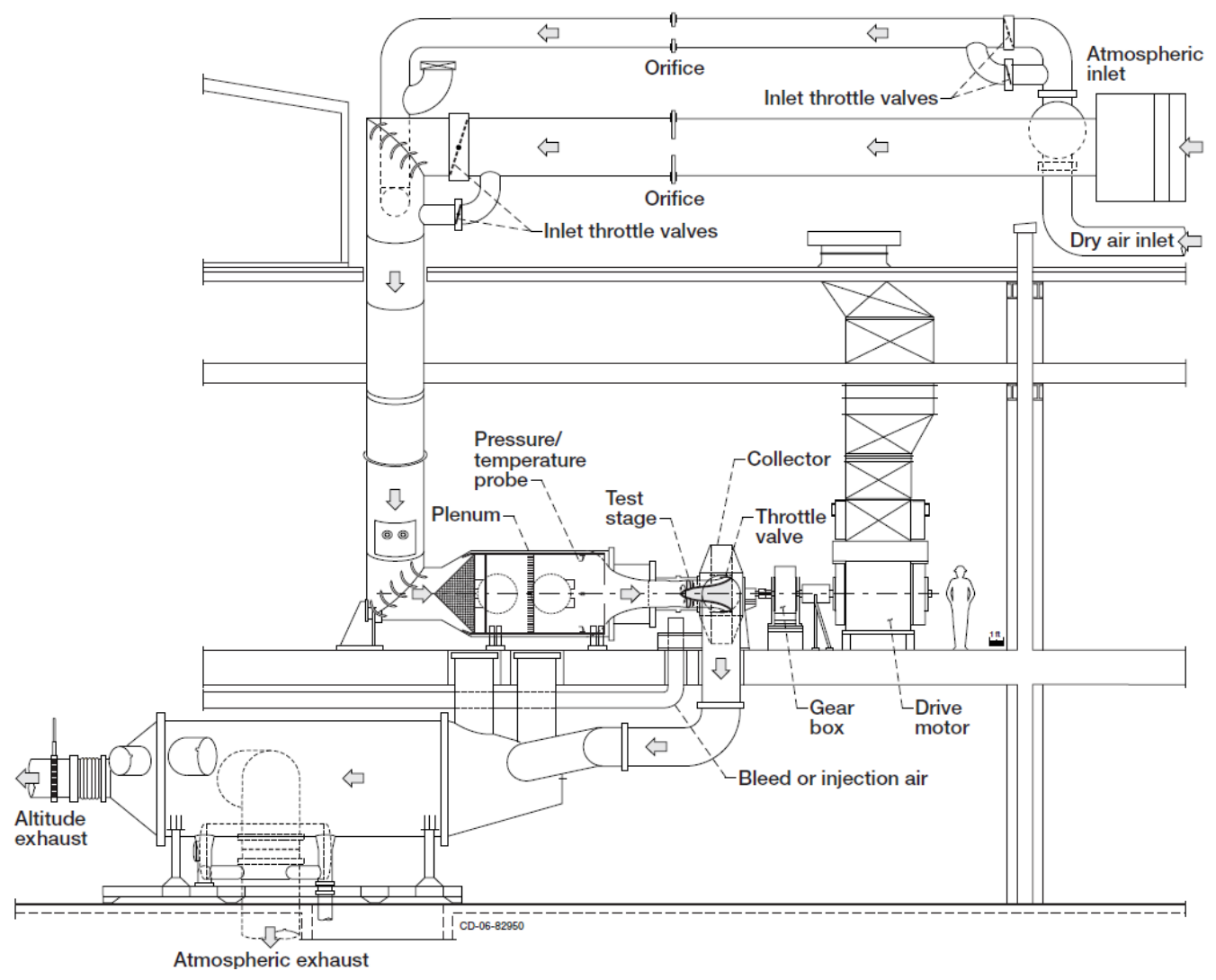

Figure 1.-Schematic of the W-8 Single Stage Axial Compressor Facility at NASA Glenn Research Center. 


\section{Test Hardware}

The Source Diagnostic Test (SDT) fan rotor (Refs. 7 and 8) was used for this test. The fan, designated R4, was designed by General Electric Aircraft Engines and is a 1/5 scale model of a high bypass turbofan. The fan has a 22 -in. $(0.559 \mathrm{~m})$ diameter with 22 titanium blades, a hub to tip ratio of 0.3 , and a design speed of $12,657 \mathrm{RPM}_{\mathrm{c}}$. The fan has a nominal hot tip clearance of $0.020 \mathrm{in} .(0.51 \mathrm{~mm})$ and tip speed of $1215 \mathrm{ft} / \mathrm{s}(370.3 \mathrm{~m} / \mathrm{s})$ at the design speed. This fan was chosen for its titanium blades, since over-the-rotor treatments have been shown to damage composite blades (Ref. 2). The data from previous testing (Refs. 7 and 8) was used to avoid stall so that blade stress measurements would not be needed during this test.

The test hardware consisted of two configurations as shown in Figure 2. The baseline was tested first and then last to check repeatability. This configuration contained a smooth, aluminum rub strip without grooves or acoustic treatment. The only over-the-rotor instrumentation in this configuration was a set of four blade tip proximity sensors equally spaced around the circumference and on the blade stacking line.

The fan case containing the acoustic treatment contains two treated sections; one over-the-rotor and one upstream of the fan. Circumferential grooves cover the entire blade chord over-the-rotor. The grooves have 67 percent open area and the groove height increases from about 2 times the groove width at the blade leading edge to about 3 times the groove width at the trailing edge. Slots in the bottoms of the grooves allow acoustic waves to enter the acoustic treatment.

A region upstream of the fan contained another set of similarly sized chambers arranged in 12 rows. These chambers were open directly to the flow surface, behind a layer of fibermetal, unprotected by grooves.

\section{Instrumentation}

Since the facility orifice plate was removed to increase the flow capacity, an alternative mass flow measurement was used. The mass flow was then measured using a correlation of corrected mass flow to the inlet static pressure (Ref. 5). This correlation has a total uncertainty of 1.0 percent. The mass flow removed through the boundary layer bleed slot is measured with an orifice plate. The bleed slot flow subtracted from the inlet mass flow calculation gives the mass flow through the fan.

Blade tip clearance sensors were installed to center the baseline case. Two thermocouples were placed in the treatment as a precautionary measure, to prevent the plastic stereolithic treatment from reaching its glass transition temperature. These thermocouples were placed at two axial locations; one at the fan face and one near the fan trailing edge.

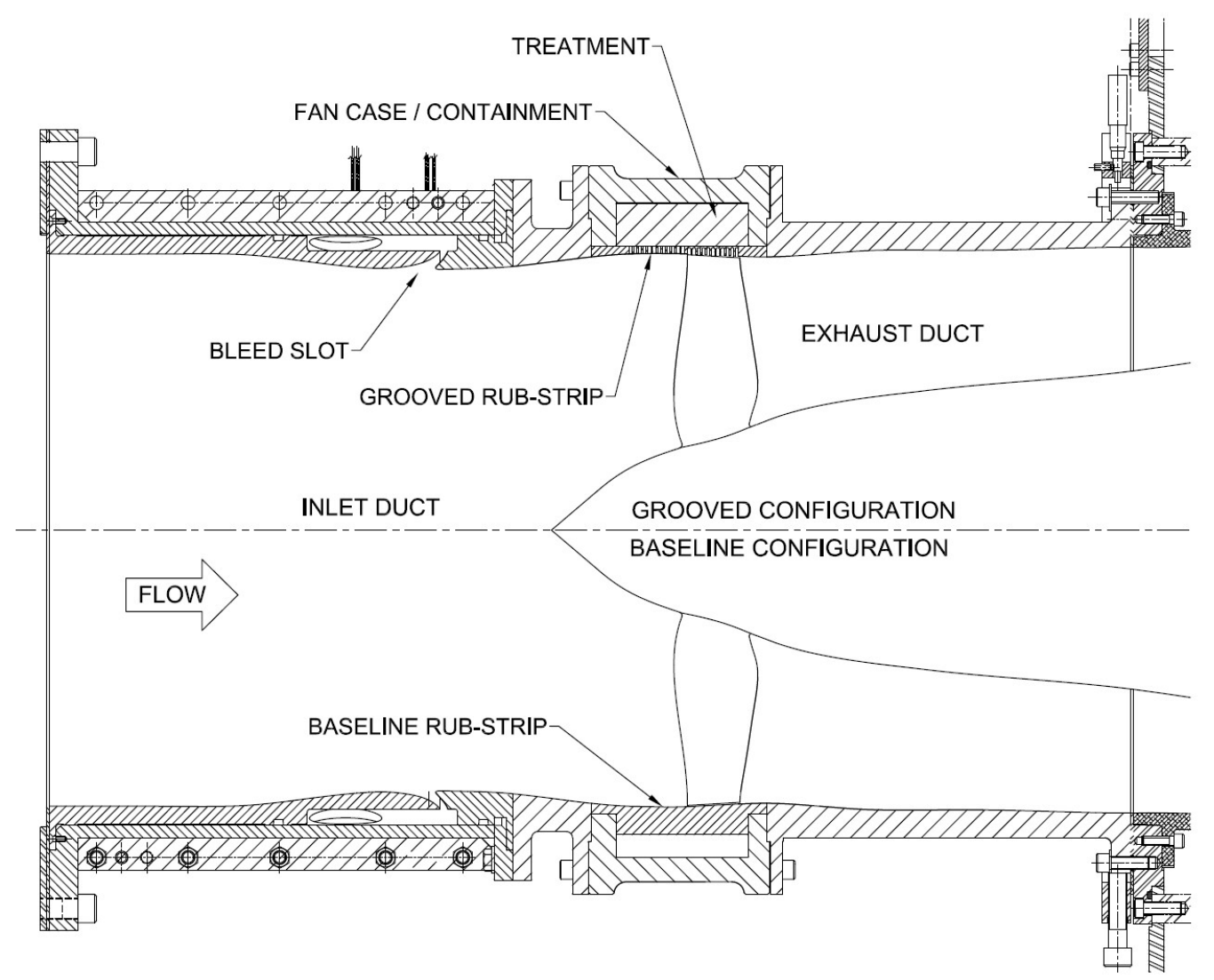

Figure 2.-Cross section of the fan with the over-the-rotor hardware identified. 


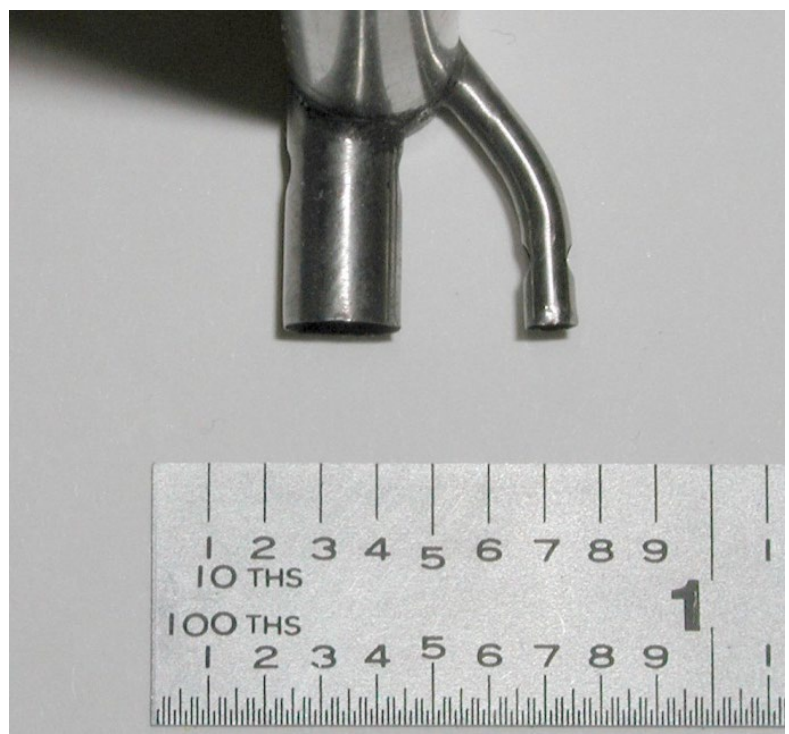

Figure 3.-Radial traversing total pressure, total temperature probe.
Static and total pressure measurements were made with the Electronically Scanned Pressure (ESP) system. These pressure measurements have an uncertainty of \pm 0.005 psi $(34.5 \mathrm{~Pa})$. Static pressure ports were located on the fan case as well as on the hub. The inlet total pressure and total temperature were measured at four circumferential stations in the plenum. The average of these four measurements is the inlet total pressure and total temperature used to calculate the fan's pressure and temperature rise. Temperatures were measured with Type E thermocouples with an uncertainty of $\pm 2{ }^{\circ} \mathrm{R}\left(1.1^{\circ} \mathrm{C}\right)$. Fan performance measurements were taken approximately 4.5 in. $(11 \mathrm{~cm})$ downstream the fan face. The fan performance measurement plane contains three total pressure rakes, three total temperature rakes, and a single radially traversing pressure and temperature probe. The pressure and temperature rakes each contain seven radially spaced, equal area ports. The traversing probe incorporates a single total pressure and total temperature measurement, as shown in Figure 3. A schematic of the fan duct with instrumentation locations is shown in Figure 4.

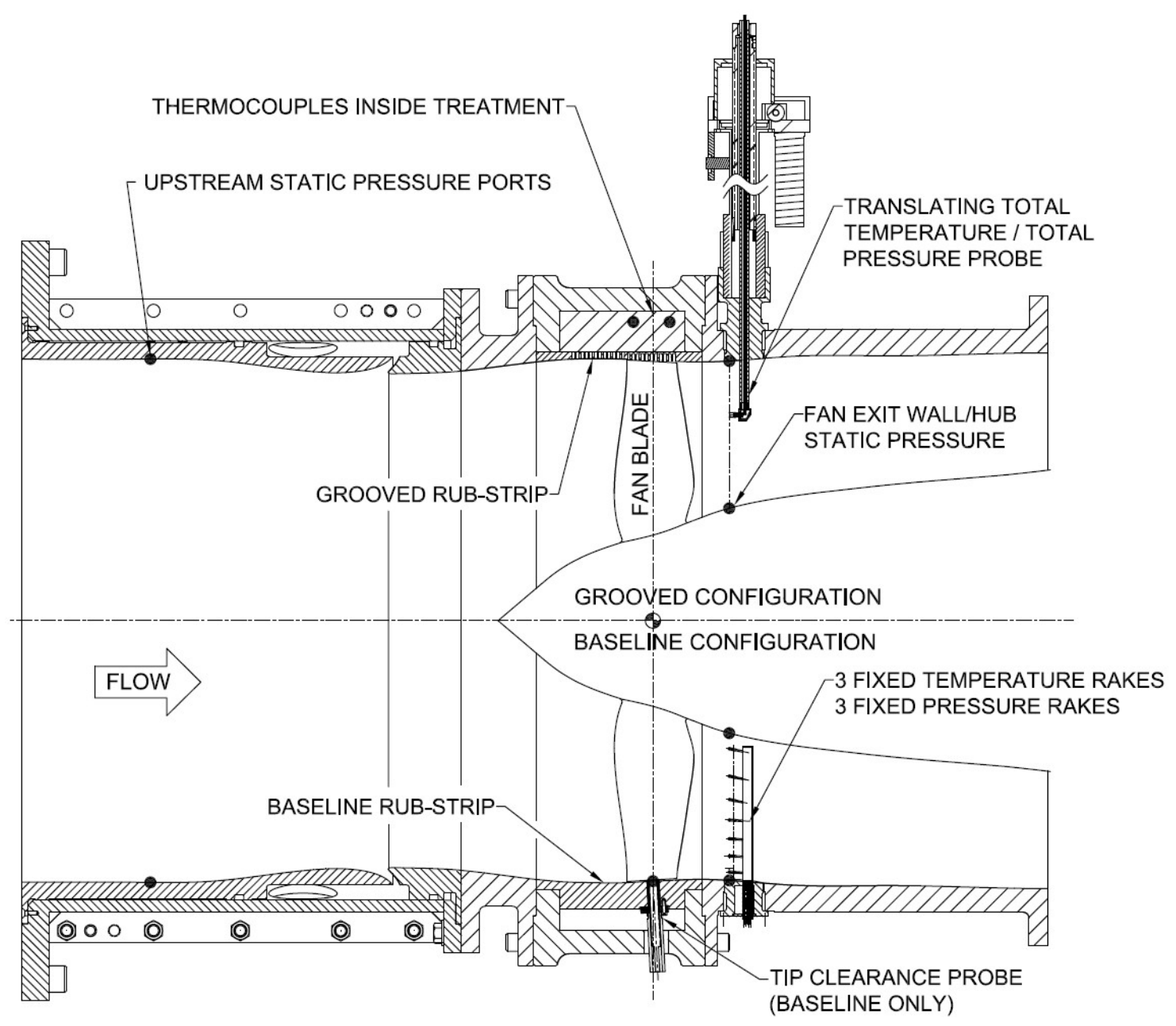

Figure 4.-Cross-section of the fan duct showing instrumentation locations. 


\section{Results}

The objective of this test was to quantify the difference between a baseline hard-wall rub strip and a rub strip with an over-the-rotor treatment. A set of fan and flow conditions were chosen for comparison with historical data. The difference in fan pressure ratio, fan temperature ratio, and fan adiabatic efficiency are presented to quantify the performance loss associated with the use of the over-the-rotor treatment.

The fan case was designed with a split section over-therotor to simplify the configuration change between the baseline and treated case. By avoiding the need to remove instrumentation between configurations, the repeatability of the results was improved. In order to quantify the repeatability of the measurements presented, the test of the baseline case was conducted before and then repeated after the test of the treatment case. The repeatability data is presented to verify the performance differences.

The conditions were set along the nominal fixed nozzle operating line for the SDT fan defined in References 7 and 8). First, the corrected fan speed was set. Then, the sleeve throttle valve, located downstream of the test section, was adjusted until the corrected mass flow was obtained. The corrected mass flow was set to within $0.3 \mathrm{lb}_{\mathrm{c}} / \mathrm{s}\left(0.14 \mathrm{~kg}_{\mathrm{c}} / \mathrm{s}\right)$ of their target value. These corrected fan speed conditions are shown in Table 1. Conditions between 50 and 87.5 percent design speed were used to represent the tip speed and fan pressure ratio of an ultra-high bypass turbofan. The 61.7 and 87.5 percent design speed were used to compare to the approach and cutback data from previous testing (Refs. 7 and 8).

The ratio of fan exit total pressure to the inlet total pressure is the pressure ratio, while the ratio of fan exit total temperature to the inlet total temperature is the temperature ratio. The fan pressure ratio and fan temperature ratio are the area averaged pressure and temperature ratios, respectively. The absolute uncertainties associated with each calculation are shown in Table 1. In order to estimate the precision/random error, 27 repeated measurements at three conditions were used to compute a 95 percent confidence interval for each parameter. These measurements were back-to-back repeats of the pressure and temperature rake data obtained during consecutive traversing probe measurements. While the absolute uncertainties for the measurements are large, the repeatability suggests that comparisons between the two rub strip configurations with the same instrumentation in the same locations are accurate within 1 percent of each measurement.

Figure 5 shows the radial variation in total pressure and total temperature ratio as measured from the average of three rakes in (a) and (b) or from a 28 point total pressure and total temperature probe traverse in (c) and (d). The results of both the rake averaged and detailed probe total pressure measurements, Figure 5(a) and (c), show that there is not significant change in total pressure ratio due to the addition of the over-the-rotor treatment. These results are consistent with the results obtained by Sutliff, et al., (Ref. 4) where a similar over-the-rotor design was used. However, the averaged total temperature rake measurements, Figure 5(b), show a temperature increase near the blade tips when the over-therotor treatment is installed, while from mid-span to the hub the temperature difference is insignificant. The total temperature probe measurements in Figure 5(d) show that the temperature increase extends from the tip to about 88 percent span at 77.5 percent of design speed.

The adiabatic efficiency $\left(\eta_{\text {adiabatic }}\right)$ at each measurement location is calculated from the pressure and temperature ratios by the formula shown below, where $\gamma$ is the ratio of specific heats for air.

$$
\eta_{\text {adiabatic }}=\frac{P R^{\gamma /(\gamma-1)}}{(T R-1)}
$$

The fan adiabatic efficiency (FAE) is then computed as the area averaged adiabatic efficiency from the total pressure and total temperature rake measurements. The computed FAEs over the range of conditions in Table 1 are shown in Figure 6. The FAE is compared against data taken with the same fan and duct geometry from the 9x15 Low-Speed Wind Tunnel in 2002 (Ref. 6). The test of the baseline case test repeated within 0.005 up to 77.5 percent of design speed. This repeatability suggests that the actual uncertainty might be less than that calculated in Table 1, but more testing would be needed to verify. As the fan speed is increased, the loss in efficiency for the over-the-rotor treatment case reduces from 0.02 at 50 percent of design speed to 0.0075 at 87.5 percent of design speed. However, all of the differences in efficiency are within the uncertainty shown in Table 1.

TABLE 1.-AEROPERFORMANCE ERRORS AND UNCERTAINTIES AT FIXED NOZZLE, NOMINAL OPERATING LINE FLOW CONDITIONS

\begin{tabular}{|c|c|c|c|c|c|c|c|}
\hline $\begin{array}{c}\text { \% design } \\
\text { speed }\end{array}$ & RPM $_{\mathrm{c}}$ & \multicolumn{2}{|c|}{$\begin{array}{c}\text { Fan total pressure ratio (PR) } \\
\text { relative errors }\end{array}$} & \multicolumn{2}{c|}{$\begin{array}{c}\text { Fan total temperature ratio (TR) } \\
\text { relative errors }\end{array}$} & \multicolumn{2}{c|}{$\begin{array}{c}\text { Fan adiabatic efficiency (FAE) } \\
\text { relative errors }\end{array}$} \\
\cline { 3 - 7 } & & $\begin{array}{c}\text { Absolute uncertainty, } \\
\%\end{array}$ & $\begin{array}{c}\text { Repeatability, } \\
\%\end{array}$ & $\begin{array}{c}\text { Absolute uncertainty, } \\
\%\end{array}$ & $\begin{array}{c}\text { Repeatability, } \\
\%\end{array}$ & $\begin{array}{c}\text { Absolute uncertainty, } \\
\%\end{array}$ & $\begin{array}{c}\text { Repeatability, } \\
\%\end{array}$ \\
\hline 61.7 & 7809 & \pm 0.52 & \pm 0.04 & \pm 16.0 & \pm 0.03 & \pm 13.9 & \pm 0.77 \\
\hline 77.5 & 9809 & \pm 0.31 & \pm 0.06 & \pm 10.7 & \pm 0.04 & \pm 8.9 & \pm 0.65 \\
\hline 87.5 & 11075 & \pm 0.23 & \pm 0.11 & \pm 8.4 & \pm 0.07 & \pm 7.2 & \pm 0.60 \\
\hline
\end{tabular}




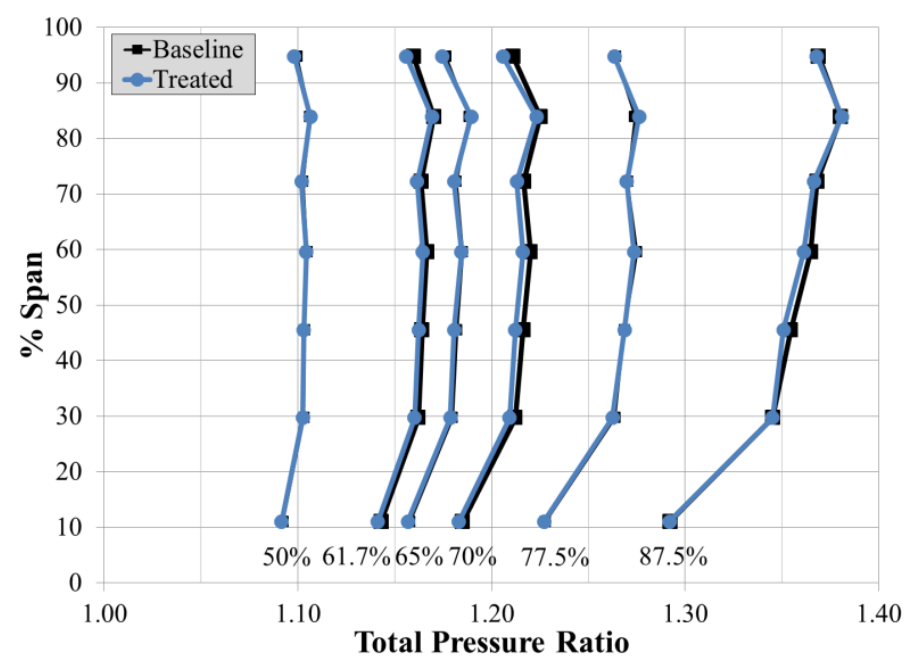

(a)

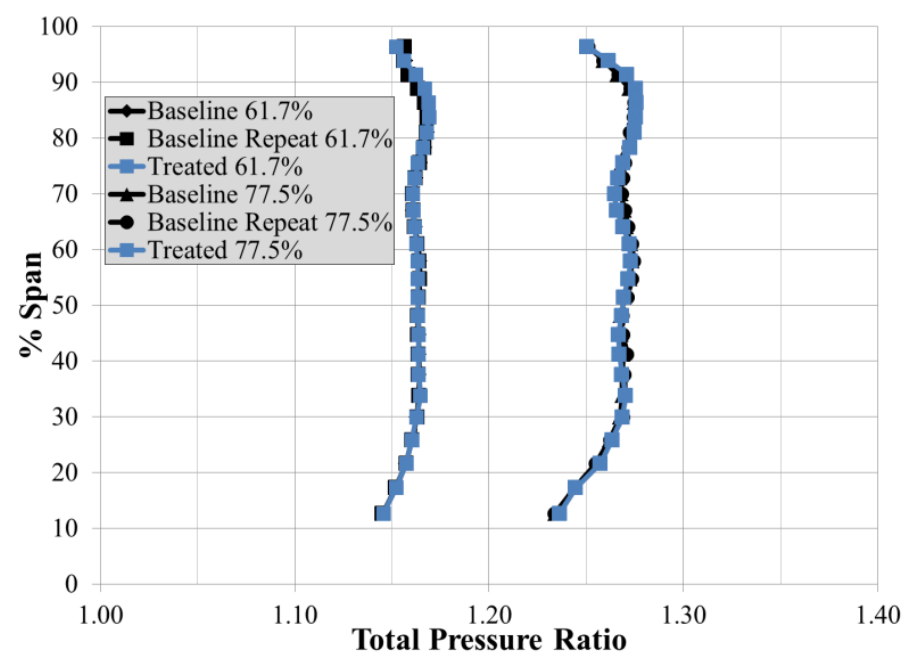

(c)

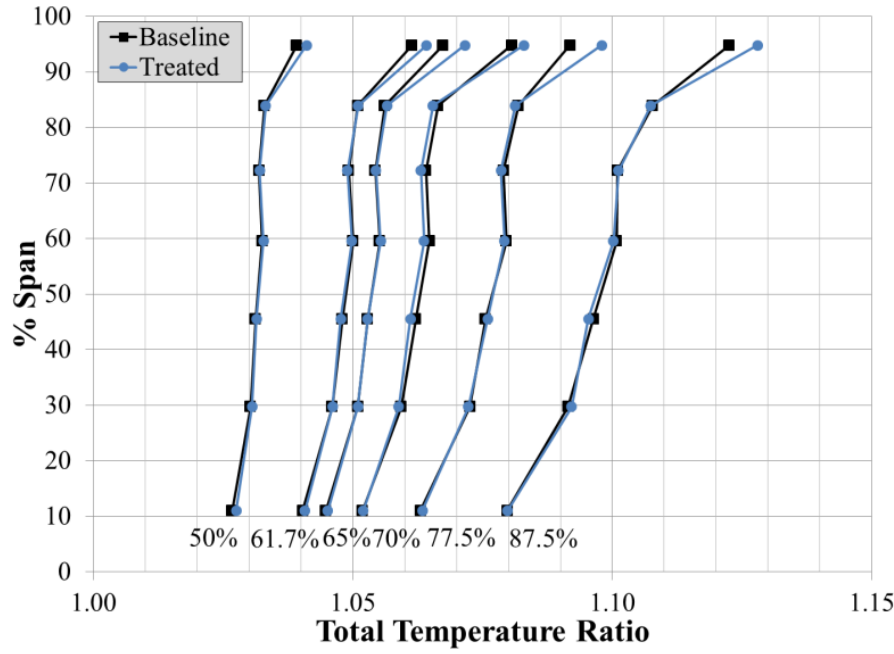

(b)

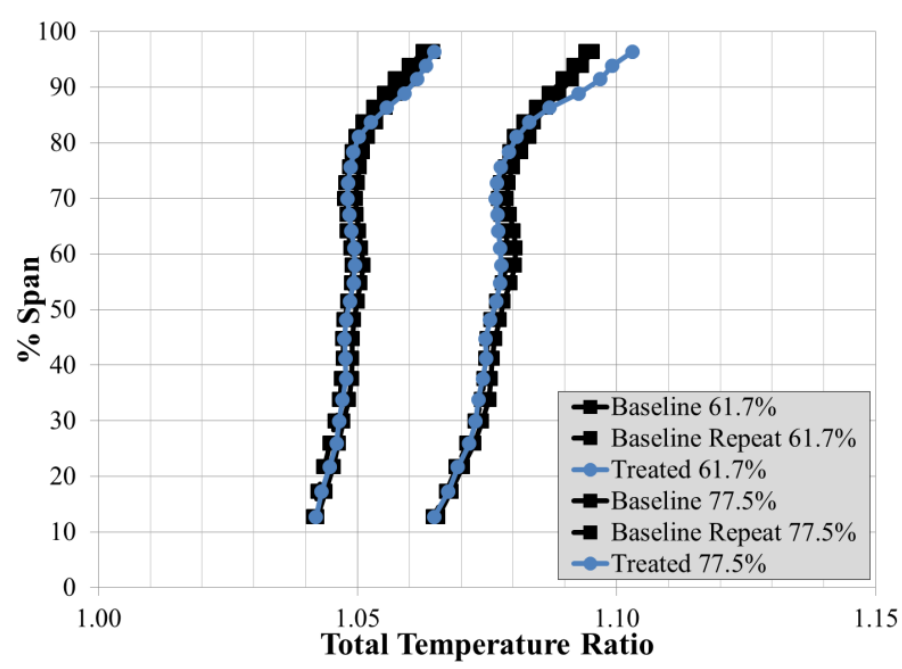

(d)

Figure 5.-Fan exit pressure and temperature profiles; rake averaged total pressure ratio (a) and total temperature ratio (b), and traversing probe total pressure ratio (c) and total temperature ratio (d). 


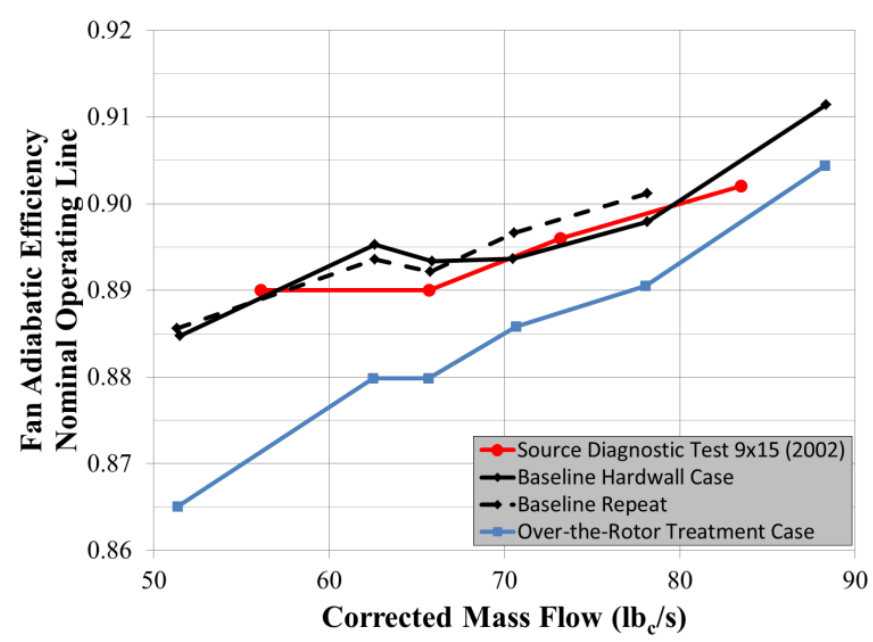

Figure 6.-Comparison of fan adiabatic efficiency on the nominal fixed nozzle operating line.

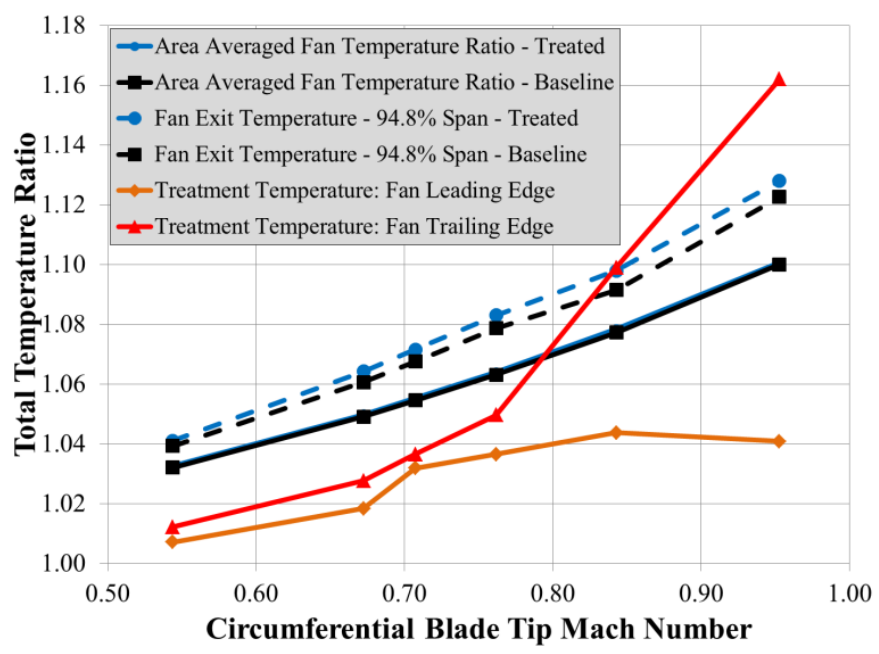

Figure 7.-Comparison of fan exit and over-the-rotor treatment temperatures with increasing circumferential blade tip Mach number.

Thermocouples in the acoustic treatment showed a significant increase in temperature when the blade tip speed approached the speed of sound. The increase in total temperature ratio of the treatment relative to that of the rake measurements is shown in Figure 7. The rapid increase of treatment temperature prevented the acquisition of performance data above 87.5 percent of design speed for the treated fan case. While the fan exit rake temperatures and treatment temperature at the fan face steadily increase, the treatment temperature near the fan trailing edge dramatically increases when the circumferential blade tip Mach number is above 0.8 .

\section{Conclusion}

An experiment was conducted in the W-8 Single Stage Axial Compressor Facility at NASA Glenn Research center to evaluate the fan performance loss of an over-the-rotor liner with a circumferentially grooved design between the blade tips and the acoustic treatment. The results of the experiment were repeatable to within 0.6 percent of fan adiabatic efficiency and consistent with the results from previous testing of the same 1.5 pressure ratio fan. While the fan pressure ratio was not affected by the over-the-rotor treatment, an increase in fan temperature ratio was seen near the blade tips. The fan performance loss was shown to be as low as 0.75 percent in terms of fan adiabatic efficiency. While the loss in adiabatic efficiency is within the absolute measurement uncertainty, the repeatability suggests that the comparison is accurate within 0.6 percent. The loss in adiabatic efficiency shows a significant improvement from previous over-the-rotor acoustic treatment designs, therefore, the acoustic benefit of the treatment will be evaluated in the 9x15 Low-Speed Wind Tunnel at NASA Glenn Research Center. Thermocouples in the acoustic treatment showed a rapid increase in treatment temperature when the blade tip speed approached the speed of sound. In order to evaluate the effectiveness of an over-therotor acoustic treatment on a fan with supersonic tip speeds, the treatment's temperature limit should be above $250{ }^{\circ} \mathrm{F}$ $\left(121^{\circ} \mathrm{C}\right)$.

\section{References}

1. Sutliff, Daniel L., and Jones, Michael G., "Foam-Metal Liner Attenuation of Low-Speed Fan Noise," AIAA 2008-2897, AIAA Aeroacoustics Conference, Vancouver, BC, May 5-7, 2008.

2. Elliott, David M., Woodward, Richard P., Podboy, Gary G., "Acoustic Performance of Novel Fan Noise Reduction Technologies for a High Bypass Model Turbofan at Simulated Flight Conditions," AIAA 2009-3140, AIAA Aeroacoustics Conference, Miami, FL, May 11-13, 2009.

3. Hughes, Christopher E., Gazzaniga, John A., "Effect of Two Advanced Noise Reduction Technologies on the Aerodynamic Performance of an Ultra High Bypass Ratio Fan," AIAA 2009-3139, AIAA Aeroacoustics Conference, Miami, FL, May 11-13, 2009.

4. Sutliff, Daniel L., Elliott, Dave M., Jones, Michael G., and Hartley, Thomas C., "Attenuation of FJ44 Turbofan Engine Noise with a Foam-Metal Liner Installed Overthe-Rotor," AIAA 2009-3141, AIAA Aeroacoustics Conference, Miami, FL, May 11-13, 2009.

5. Bailey, Everett E., "Effect of Grooved Casing Treatment on the Flow Range Capability of a Single-Stage Axial Flow Compressor,” NASA TM X-2459, Jan., 1972. 
6. Hathaway, Michael D., "Passive Endwall Treatments for Enhancing Stability," NASA/TM-2007-214409, Jul., 2007.

7. Van Zante, Dale E., Podboy, Gary G., Miller, Christopher J., Thorp, Scott A., "Testing and Performance Verification of a High Bypass Ratio Turbofan Rotor in an Internal Flow Component Test Facility," GT2007-27246 or NASA/TM-2009-215661, Turbo Expo 2007, Montreal, QC, May 14-17, 2007.
8. Hughes, Christopher E., Jeracki, Robert J., and Miller, Christopher J., "Fan Noise Source Diagnostic Test Rotor Alone Aerodynamic Performance Results," AIAA 2002-2426 or NASA/TM-2005-211681, AIAA Aeroacoustics Conference, Jun. 17-19, 2002.

9. Nark, Douglas M., and Jones, Michael G., "Broadband Liner Optimization for the Source Diagnostic Test Fan," AIAA 2012-2195, AIAA Aeroacoustics Conference, Colorado Springs, CO, Jun., 4-6, 2012. 



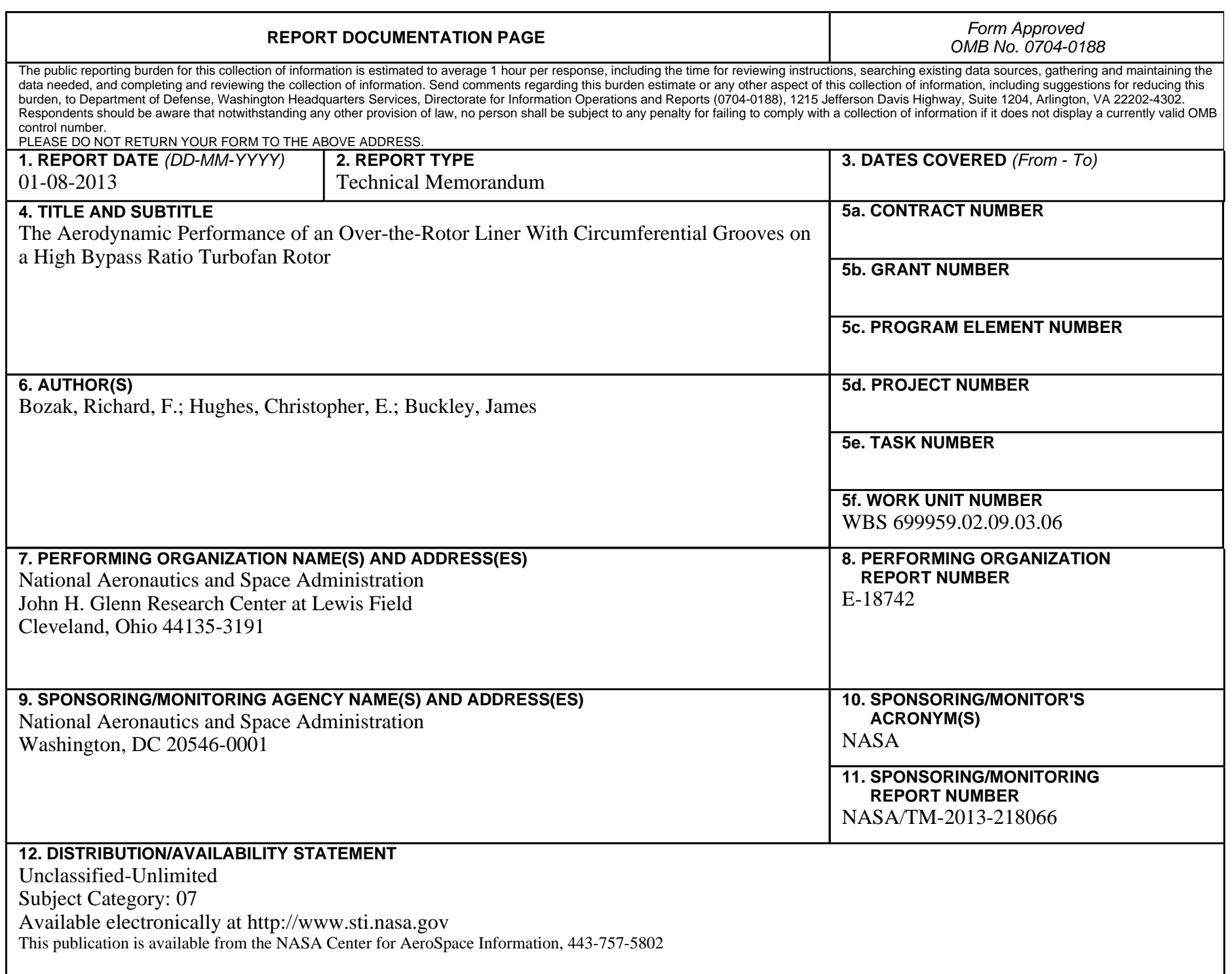

\section{SUPPLEMENTARY NOTES}

\section{ABSTRACT}

While liners have been utilized throughout turbofan ducts to attenuate fan noise, additional attenuation is obtainable by placing an acoustic liner over-the-rotor. Previous experiments have shown significant fan performance losses when acoustic liners are installed over-the-rotor. The fan blades induce an oscillating flow in the acoustic liners which results in a performance loss near the blade tip. An over-the-rotor liner was designed with circumferential grooves between the fan blade tips and the acoustic liner to reduce the oscillating flow in the acoustic liner. An experiment was conducted in the W-8 Single-Stage Axial Compressor Facility at NASA Glenn Research Center on a 1.5 pressure ratio fan to evaluate the impact of this over-the-rotor treatment design on fan aerodynamic performance. The addition of a circumferentially grooved over-the-rotor design between the fan blades and the acoustic liner reduced the performance loss, in terms of fan adiabatic efficiency, to less than 1 percent which is within the repeatability of this experiment.

15. SUBJECT TERMS

Over-the-rotor; Turbofan; Performance

\begin{tabular}{|c|c|c|c|}
\hline \multicolumn{3}{|c|}{ 16. SECURITY CLASSIFICATION OF: } & \multirow{2}{*}{$\begin{array}{l}\text { 17. LIMITATION OF } \\
\text { ABSTRACT } \\
\text { UU }\end{array}$} \\
\hline $\begin{array}{l}\text { a. REPORT } \\
\text { U }\end{array}$ & $\begin{array}{l}\text { b. ABSTRACT } \\
\text { U }\end{array}$ & $\begin{array}{l}\text { c. THIS } \\
\text { PAGE } \\
\text { U }\end{array}$ & \\
\hline
\end{tabular}

\begin{tabular}{|l|l|}
\hline $\begin{array}{l}\text { 18. NUMBER } \\
\text { OF } \\
\text { PAGES }\end{array}$ & $\begin{array}{l}\text { 19a. NAME OF RESPONSIBLE PERSON } \\
\text { STI Help Desk (email:help@sti.nasa.gov) }\end{array}$ \\
\cline { 2 - 2 } & $\begin{array}{l}\text { 19b. TELEPHONE NUMBER (include area code) } \\
\text { 443-757-5802 }\end{array}$ \\
\hline
\end{tabular}



